\title{
Dynamic networks in early international agrobusiness
}

\section{ChRistiam Mendez LAZARTE ${ }^{1}$}

\author{
1 UNIVERSIDAD DE LIMA / INSTITUTO DE INVESTIGACIÓN CIENTífICA DE LA UNIVERSIDAD DE LIMA, LIMA, PERU
}

\begin{abstract}
This research aims to understand the benefits of networks, based on their origin, for the process of companies' accelerated internationalization. The study adopts as a reference the emergence of Born Global enterprises, International New Ventures (INV), and the Networking approach. An inductive and interpretative method was applied, using in-depth interviews, triangulated with public documents about the studied companies. The research analyzed two companies oriented to international markets since their establishment. The interviews' transcripts were analyzed using matrices elaborated throughout the study, which were interrelated with the elements of early international business, identified in the interviewees' responses. The analysis allowed the development of a chronology of the cases, and the networks' origin, benefits, and strategies related to the accelerated internationalization model were identified. The results showed a diverse typology of networks by origin: family, previous work experience, academic (Undergraduate and Graduate), events, institutional (public and private), and partners. These networks promote the process of accelerated internationalization with: contacts, emotional support, knowledge (lessons, experiences, among others), resources (monetary and non-monetary), forming teams and networking, which are elements of the Born Global and INV companies. The research concludes that the scenario of products with low local demand and niches in the international markets form an appropriate context for the emergence of Born Global or INVs, and that networks in the first stage (even before the companies foundation) guide the internationalization strategies. These strategies support the growth and evolution of networks the company is connected to throughout its development process.
\end{abstract}

Keywords: International New Ventures. Born Global. Agrobusiness. Networking.

\section{Dinâmica de redes no agronegócio de internacionalização rápida}

\section{Resumo}

Este estudo visa compreender os benefícios oferecidos pelas redes no processo de rápida internacionalização dos empreendimentos de agronegócio, em base aos tipos de rede (classificadas pela origem). O estudo adotou como referência a emergência de empresas do tipo Born Global and International New Ventures (INVs), bem como a abordagem do Networking. A pesquisa usa um método indutivo e interpretativo baseado em entrevistas em profundidade, trianguladas com informações sobre as empresas (obtidas através de documentos disponíveis em agências governamentais e online). Foram selecionadas duas empresas que, desde sua criação, são voltadas ao mercado internacional. A transcrição das entrevistas foi analisada com uso de matrizes elaboradas ao longo do estudo, relacionando os fatores relevantes a esse tipo de empreendimento e aos tipos de rede. A análise permitiu elaborar uma cronologia de eventos nas empresas estudadas, identificando as redes presentes na origem de cada uma delas, os benefícios relacionados aos tipos de rede, e as estratégias adotadas no modelo de rápida internacionalização. Os resultados mostraram uma diversidade de redes, identificadas por sua origem: redes familiares; oriundas de experiências anteriores de trabalho; redes acadêmicas (graduação e pós-graduação); formadas em eventos ou em instituições (públicas e privadas); redes dos sócios da empresa. Essas redes promovem o processo de rápida internacionalização por meio de contatos, apoio emocional, formação (treinamento, troca de experiências, entre outros), recursos (financeiros e outros), formação de equipes e networking (conexão com mais redes), elementos importantes no modelo de empresas Born Global ou INVs. O estudo conclui que a produção agroindustrial com baixa demanda local, mas com nichos de mercado internacional forma um contexto adequado para o desenvolvimento de empresas Born Global ou INVs, e que as redes presentes no estágio imediatamente anterior a fundação das empresas orientam as suas estratégias de internacionalização. As estratégias escolhidas, por sua vez, guiam o crescimento e a evolução das redes que seguem fazendo parte do contexto nas demais etapas de desenvolvimento da empresa.

Palavras-chave: International New Ventures. Born Global. Rápida internacionalização. Agronegócios. Redes.

\section{Dinámica de redes en agronegocios de rápida internacionalización}

\section{Resumen}

La presente investigación se orienta a comprender los beneficios que generan las redes según su origen en el proceso de internacionalización acelerado de los emprendimientos. Se tomó como referencia el surgimiento de Born Global, International New Venture (INV) y el enfoque de Networking. Se aplicó un método inductivo e interpretativo mediante la técnica de entrevistas en profundidad, triangulada con información pública disponible. Se seleccionó dos empresas con orientación a los mercados internacionales, desde sus primeros años de creación. Se analizaron los transcripciones mediante matrices, que se interrelacionaron con los constructos identificados en los entrevistados. El análisis permitió la elaboración de una cronología de los casos para luego identificar a las redes por origen, beneficios y estrategias que se relacionan con el modelo de internacionalización acelerado. Los resultados mostraron una tipología diversa de redes por origen: familiares, experiencia de trabajo previa, académicas (pre-grado y post-grado), eventos, institucionales (públicos y privados) y socios, que promueven el proceso de internacionalización acelerado con: contactos, soporte emocional, conocimiento (lecciones, experiencias, entre otros), recursos (monetario y no monetario), confirmación de equipos y contactos (más redes), en los factores del modelo de Born Global y International New Venture. La investigación concluye que los productos con baja demanda local y con nichos de mercado internacionales son un contexto adecuado para el surgimiento de Born Global o International New Venture, y que las redes en la etapa de pre - fundación orientan la estrategia de internacionalización, y estas a su vez guían el crecimiento y evolución de las redes en las etapas del proceso emprendedor.

Palabras clave: International New Ventures. Born Global. Rápida internacionalización. Agronegocios. Redes. 


\section{INTRODUCTION}

Since 1994, McDougall and Oviatt have identified the rapid internationalization of small- and medium-sized enterprises (SMEs) emerging into a global context of greater market openness. In this sense, the International Entrepreneurship approach focuses on explaining the accelerated internationalization process of enterprises, making it useful for expanding research in this field (COVIELLO, 2006).

These companies have skipped the incremental stage and/or have had an international market orientation from their inception. Oviatt and McDougall define an international new enterprise as: "[...] a business organization that, from its inception, seeks to derive significant competitive advantage by the use of resources and sale of products in multiple countries" (OVIATT and MCDOUGALL, 1994).

An increasing number of industries and businesses are affected by environmental factors and enterprises are expected to internationalize faster (RIALP-CRIADO, RIALP-CRIADO, URBANO et al., 2005). Studies have constantly identified these ventures as being in the new business and/or technology-intensive sectors as they are most affected by globalization. This has consequently turned them into high-tech sectors and highly competitive markets and sectors where most Born Global or International New Venture companies have been found (BELL, 1995; OVIATT and MCDOUGALL, 1996; COVIELLO and MUNRO, 1995; JONES, 1999; AUTIO and SAPIENZA, 2000; BURGEL and MURRAY, 2000; ROBERTS and SENTURIA, 1996; SHARMA and BLOMSTERMO, 2002; ZAHRA, IRELAND, and HITT, 2000). However, market openness and agricultural export growth in Peru make it necessary for us to perform an analysis in that sector.

Unlike multinational companies, newly established ones with "scarce resources," such as Born Globals or INVs, tend to favor exporting as their primary entry mode because of the high degree of international business flexibility (KNIGHT and CAVUSGIL, 2004).

Rapid internationalization of these medium-sized companies is conditioned by multiple reasons such as the environment in which they are established (RIALP-CRIADO, RIALP-CRIADO, URBANO et al., 2005), entrepreneurial traits, risk-taking ability, previous international experience (CANNONE, COSTANTINO, PISONI et al., 2012), their entrepreneurial profile (FEDERICO, KANTIS and RIALP et al., 2009), strategy, resource capacity and equipment in organization (FEDERICO, KANTIS and RIALP et al., 2009); and networks (JONES and COVIELLO, 2005).

This research focuses on agribusiness cases with early international market orientation and displays how different types of networks contribute to the rapid internationalization thereof through different development stages.

\section{THEORETICAL FOUNDATION}

\section{Born Global - International New Venture}

The establishment of a Born Global or International New Venture enterprise depends on the environment, entrepreneurial traits (risk-taking ability, previous international experience, and entrepreneurial profile), networks (family and personal ties, as well as public and private institutions), and the organization (strategy, resource capacity, and equipment).

The environment is a relevant factor, as international market expansion since the mid 90's in some countries has guided SMEs toward new niche markets and access to technology development, the growth of networks and global alliances, as well as improved entrepreneurial skills (RIALP-CRIADO, RIALP-CRIADO, URBANO et al., 2005). However, this environment varies depending on the country, and as Kantis proposes, in Latin America, and particularly in Peru, there are still multiple growth opportunities (KANTIS, FEDERICO and IBARRA GARCÍA, 2016). 
Figure 1

Born Global / International New Venture Model

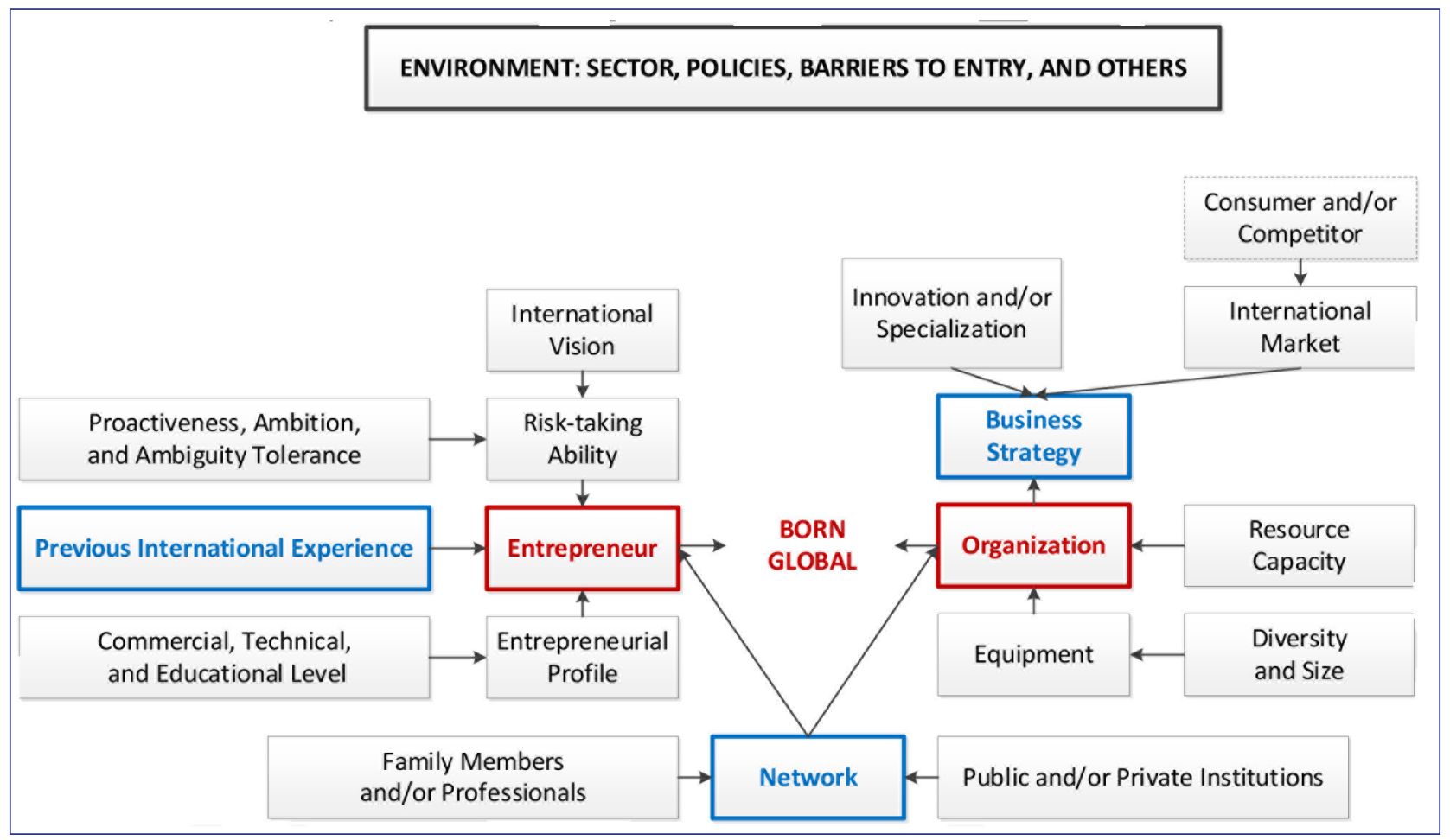

Source: Elaborated by the author (2018).

In Peru, a study on the Born Global theory versus the Uppsala model underlined the opportunities for rapid internationalization companies to create an export business foundation in the Information and Communication Technology industry (MÉNDEZ, 2015). This study reveals the need to identify sectors that have high potential for enterprises with an early international market orientation, as such enterprises are not solely found in the Peruvian technology sector because they are still at the development stage.

According to several studies in this field, Born Globals and INVs are entrepreneurial firms whose managers/management class (founders) appear to view the whole world as their marketplace from the onset (RENNIE, 1993; KNIGHT and CAVUSGIL, 1996; MADSEN and SERVAIS, 1997; ASPELUND and MOEN, 2001; SHARMA and BLOMSTERMO, 2002; GABRIELSSON and KIRPALANI, 2004; OVIATT and MCDOUGALL, 1994; ANDERSSON and WICTOR, 2003; CHETTY and CAMPBELL-HUNT, 2004).

Neither do these ventures confine themselves to a single country nor see foreign markets as merely complementary to domestic ones. Therefore, they have a broader view of a target market upon venture establishment. Previous international experience of early internationalization founders is another factor, as proposed by authors such as Cannone, Costantino, Pisoni et al. (2012).

\section{International Networks and Ventures}

The international market is generated by relationship networks between enterprises and they are considerably complex, making it difficult to identify patterns. Solid and committed networks reduce the psychic distance and accelerate the internationalization process (JOHANSON and VAHLNE, 2009).

This makes third party participation an important mechanism for acquiring and developing network ties (ELLIS, 2000; HINTTU, FORSMAN, and KOCK, 2003; EVERS and KNIGHT, 2008). Network ties allow knowledge gained from the experiences of hightech companies' to be shared through the support provided by interpersonal relationships (ARENIUS, 2002; COVIELLO and MUNRO, 1995). 
A multi-case study of Nicole Coviello, one of the most representative authors on international business networks, analyzes network dynamics in the early rapid internationalization stage, contributing significantly to the network theory and the relationship thereof with international business (COVIELLO, 2006). Authors such as Sharma and Blosmtermo (2003) analyze networks of rapid internationalization ventures.

Research usually approaches five aspects when exploring rapid internationalizing enterprises (RIEs) and networks: classification, benefits, characterization, relationship strategy, and evolutionary patterns and they are usually analyzed in a fragmentary manner.

Networks can therefore be classified in several ways, for example, by the environment of origin: family, academic, or business networks. According to Hallen (1992), this is a network infrastructure made up of social and business actors that relate to each other in a direct and indirect manner and are not necessarily linked to sales and purchases, while (HOLMLUND and KOCK, 1998) argue that these networks represent a capital of trust.

Scientific research on international business assigns greater importance to personal and professional networks as a factor contributing to rapid internationalization and the identification of international business opportunities.

In Latin America, Kantis' research is an example of professional network importance that compares enterprises from European and Latin American countries (FEDERICO, KANTIS, and RIALP et al., 2009).

Networks generate benefits such as credibility and access to critical resources including knowledge, alliances, and other cooperation strategies (FALIZE and COEURDEROY, 2012; CANNONE, COSTANTINO, PISONI et al., 2012; MCDOUGALL and OVIATT, 2003).

Through knowledge, networks also contribute to the creation and/or international level improvement of a highly competitive product. They are the key to market access, introduction to international customers, and/or markets and they reduce entry constrictions.

Networks are generated and consolidated through knowledge (BURT, 1997; GULATI, 1995). Knowledge is information validated by preliminary tests that enable its use without experience (LIEBESKIND, 1996).

In other words, networks provide tangible and intangible resources such as financing, knowledge, and experience (EVERS and KNIGHT, 2008). Networks are comprised of actors that provide information, knowledge, references, and financial resources for enterprise internationalization (GALASKIEWICZ and ZAHEER, 1999).

Another network benefit is the introduction to the international consumer market and/or customers to enable early business creation through high network dynamics. Networks are a source of information that define the target market (BURT, 1997), allowing early and correct decision-making. Oviatt and McDougall (1994) found that networks allow INVs to access markets, sources of finance, distribution channels, and contacts for external growth.

International ventures have to use their best endeavors to build credibility and trust with their foreign partners, and thus, establish their presence in the international market. Credibility and trust develop incrementally by working together (BUCKLIN and SENGUPTA, 1993; LARSON, 1992).

Some authors, such as Coviello (2005) argue that networks are very important in the early internationalization stage: "[...] research could examine the extent to which network structure and internationalization behavior self-reinforce. That is, how network structures influence internationalization and how internationalization influences network structures over time" (JONES and COVIELLO, 2005, p. 299).

Through the benefits generated, networks can influence strategic decisions because they are involved in sharing resources between different members (SHARMA and BLOMSTERMO, 2003).

Mort and Weerawardena (2006) argued that Born Global firms are vulnerable since they frequently dependent on a single product that they have first commercialized in lead markets (MADSEN and SERVAIS, 1997; JOHANSON and MATTSSON, 1988; OVIATT and MCDOUGALL, 1994; COVIELLO and MUNRO, 1997). Therefore, they develop networks as an expansion strategy.

Linkages generating and strengthening the enterprise internationalization process are established through networks that help them adapt to an internationalization strategy, thereby accelerating network ties in the internationalization process 
(MAJKGARD and SHARMA, 1998; SHARMA and BLOMSTERMO, 2003). This has also been understood as "social capital" and has a significant role in small- and medium-sized enterprises (ARENIUS, 2002).

One of the most relevant aspects for an enterprises rapid internationalization is the creation and/or improvement of a highly competitive product on an international level. It is related to the product being marketed, since this specialization helps them adapt to international markets and adjust to resource limitations thereof (FERREIRA, SANTOS, and SERRA, 2010). Studies conducted by Ritter and Gemünden (2003) and Chetty (2004) examined the development of knowledge-intensive products through networks.

According to their evolution pattern, networks can be dispersed or concentrated, linear or circular, and cyclical. Nodes are other relevant aspects in some network research studies that propose configuration patterns. Sharma (2002) argues that the Global Born process is non-linear because these relationships support each other from both directions and can either direct or indirect. While Coviello (2006) states that they can evolve throughout the business life cycle, even before incorporation. Jones (1999), Sharma and Blomstermo (2003) argue that INVs do not have a network behavior pattern.

Finding a common network pattern is a complex and vague issue, as stated by Coviello (2006, p. 724) "[...] no one pattern explains the nature of ties in INV networks. Ties can be either social or economic, and either strong or weak. As an example, although early internationalization could have been triggered because of economic ties, some social ones also contributed through network evolution."

However, the time evolution of a network relationship is important since it highlights the maturation of international relations (HAYES, WILSON, GIFFORD, et al., 1996). Coviello (2006) argues that networks grow and evolve over time, and density is related to enterprise evolution.

The literature review on network dynamics in an enterprises rapid internationalization highlights the opportunity to study the relationship between classification, benefits, characteristics, relationship with strategies, and network growth patterns, aiming at a comprehensive view of the network phenomenon.

\section{METHODOLOGY}

We applied an inductive and interpretative method to gain insight into the enterprise's founders' behavior. Qualitative research methodology has been used from the onset of International Entrepreneurship, and a case or multiple cases have been selected for an empirical study proposal on this new phenomenon. Case studies provide an exploratory approach on the reasons and motivations for international small - and medium-sized enterprise behavior (BELL, 1995; COVIELLO and MUNRO, 1995; COVIELLO and MUNRO, 1997; HOLMLUND and KOCK, 1998; CHETTY and BLANKENBURG-HOLM, 2000)

We began the research process with an environment analysis to identify subsector cases that meet the required characteristics. In order to do so, we used the Peruvian Customs and National Superintendency of Tax Administration database (SUNAT, by its acronym in Spanish) to manually crosscheck data, as well as snowball sampling with incubator references to find enterprises that meet selection criteria.

We selected the non-traditional agricultural export sector for two main reasons: the sector's importance and growth in Peru and because there is scarce research on International Entrepreneurship cases in this sector. Based on INV and Born Global definition, we performed an exploratory database sweep and selected two enterprises with an early international market orientation. Sanitary barriers that restrict early sale in the agricultural export sector were considered; by contrast, while one of the cases develops a product innovation strategy, the other is oriented toward marketplace. We selected these cases after considering recommendations of the National Center for Research Methods Review Paper (BAKER and EDWARDS, 2012). 
As a data collection method, we used in-depth interviews with founders and the triangulation of information available about enterprises, such as their export behavior according to Peruvian Customs and SUNAT. The data was complemented with information available on the internet about the entrepreneur and the enterprise, as well as participant observation (EISENHARDT, 1989; YIN, 1994).

In both cases, we conducted an interview lasting more than one hour, once a year for approximately three years. Extensive communication helped us build trust with entrepreneurs who expressed their perceptions and beliefs without direct questions in the first interviews (STRAUSS and CORBIN, 1990). As a result, they reported the difficult episodes in their relationships and differences among the parties. The research guide contained open-ended questions that encouraged interviewees to share their entrepreneurial experience chronologically and by freely assigning importance to the networks used and developed.

The analysis began with a case chronology, as recommended by several research studies on enterprise internationalization and then focused on network dynamics. We approached these cases using a longitudinal study, starting from a moment in time. Thus we could assess the evolutionary network strategy dynamics. Research on internationalization processes focused on stage sequence, even starting from pre-incorporation, thus a chronological analysis was required, as proposed by Johanson and Vahlne (1992) and Melin (1992). It should be noted that context is an important aspect of the internationalization process, whose interpretation requires the analysis to avoid bias (HUNT, 1991).

We developed matrix analyses, relating relevant factors of rapid internationalization enterprise to network typology and identifying the tangible network benefits throughout its development stages.

\section{RESULTS}

\section{Local context}

In Hugo Kantis' (the most outstanding local researcher on entrepreneurship) most recent research on Latin America, he demonstrates that Peru has not strengthened its entrepreneurial ecosystem yet, ranking it among the last of the countries to be strengthened in the region (KANTIS, FEDERICO and IBARRA GARCÍA, 2016).

However, Peru ranks among the world's top 10 food supplying countries, with various products such as asparagus, coffee, mango, grapes, quinoa, dried fruit, beans, tangerines, ginger, onions, and fresh peas (GESTIÓN, 2016).

Figure 2

Evolution of Peruvian Exports

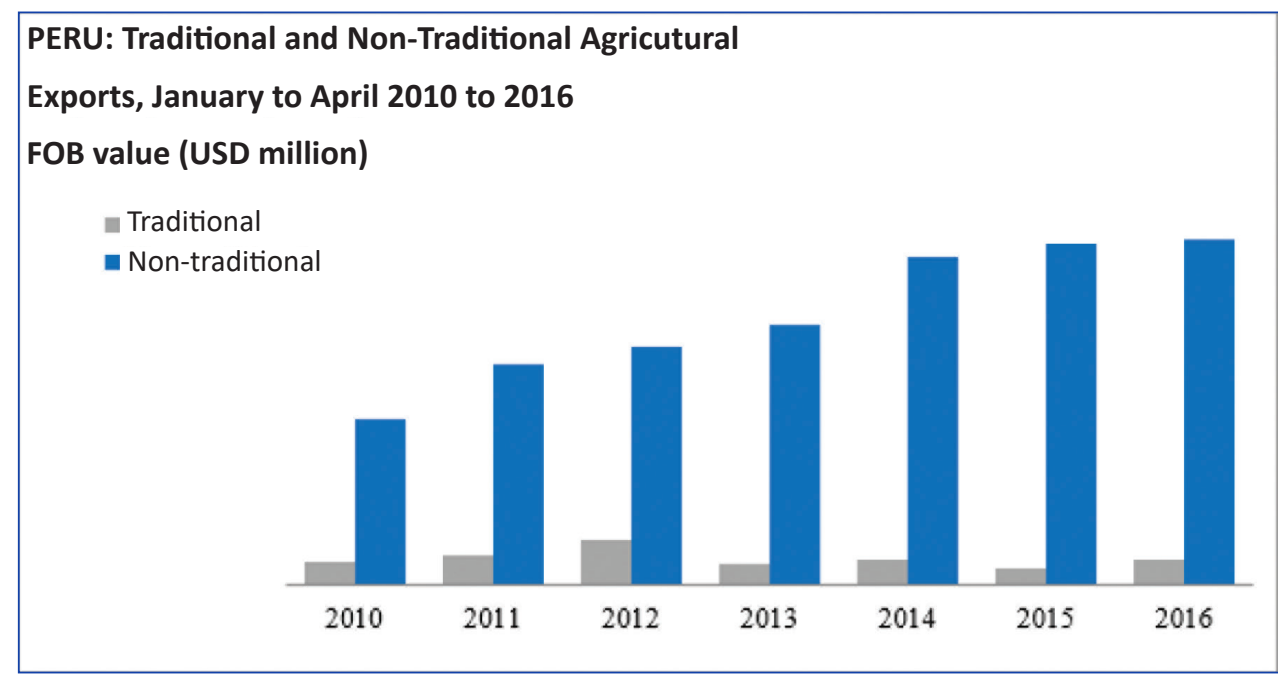

Source: Kevin Zúñiga, Diario La República (2016). 
This growth focuses on Peruvian biodiversity and its development potential in Peru, which contains 86 of the planet's 117 life zones. Peru has 73 million hectares of forests, 182 plant species, and 5 species of wild fauna.

According to a report from the Central Reserve Bank of Peru, the growth of non-traditional agricultural export sector is mainly due to technological development, increase in yield per hectare, proper health work, where the National Agrarian Health Service had an important role, and lastly, the target market orientation through free trade agreements and an export supply promotion (VASQUEZ, 2015).

By analyzing the Customs and SUNAT database and applying the snowball sampling, we found some characteristics that could facilitate and guide the search for rapid internationalization enterprises in Peru by having the target market as a reference.

\section{Box 1}

Type of Enterprise According to Target Markets (2017)

\begin{tabular}{|c|c|c|}
\hline MARKETS & International Mass Market & International Market Niche \\
\hline Domestic Mass Market & Large enterprise & $\begin{array}{c}\text { Large- and medium-sized } \\
\text { enterprises }\end{array}$ \\
\hline Non-Existent Domestic Market & $\begin{array}{c}\text { Large- and medium-sized } \\
\text { enterprises }\end{array}$ & Medium enterprises \\
\hline
\end{tabular}

Source: Elaborated by the author (2018).

\section{Case profile}

We considered two cases with early international orientation. Both are product-oriented businesses that focus on plants (seaweed and moss) marketed in international niche markets and are shown in the fourth quadrant of the figure: "Type of Enterprise According to Target Markets."

\section{Case 1}

\section{Enterprise Profile}

The enterprise is dedicated to development, production, and marketing of products based on Peruvian main seaweed resources. It was established by two entrepreneurs in 2008. Currently, it is the only national enterprise that develops seaweed products and farming. It has more than 60 products and is present in 11 countries such as Costa Rica, Colombia, Ecuador, Chile, Bolivia, Argentina, Panama, Guatemala, Nicaragua, Japan, and Australia.

\section{Entrepreneurial Profile}

The entrepreneur is the main partner and founder. He is a fishing engineer specialized in aquaculture at the National Agrarian University La Molina. He graduated in 1993 and gained experience in project development because of his research skills and assistance to his professors in consultancy.

He had decided early on to become an entrepreneur and specialize in aquaculture; he assessed the opportunity of venturing into fish and prawn projects, but finally decided on seaweed after learning about seaweed cooperatives in Chile. In 1994, the entrepreneur took a specialization course in seaweed at the National University of San Marcos that he considers very important, since it was never repeated in Peru and he had the most important seaweed "gurus" of South America. One of them was a seaweed expert from the University of Sao Paulo, who recommended him a course on mollusks with people he knew from the Universidad Católica del Norte of Chile. Following that recommendation, in 1995 he was awarded a scholarship by the Japanese International Cooperation Agency (JICA) to attend this course in Chile. There he met his second seaweed mentor and also took the opportunity to learn about seaweed and laboratory-related facilities.

He also used these academic contacts as a social capital platform for his later entrepreneurial experiences. 


\section{Pre-seed Stage}

In 1995, the entrepreneur set up a seaweed farming enterprise with two capital investors he had met through his family network. The entrepreneur began seaweed farming in San Juan de Marcona - Ica. The enterprise invested significant money and effort in the first stage of product manufacturing. Nevertheless, due to a climatic event and illegal seaweed extraction practices, the enterprise went bankrupt in 1998. Then, the main entrepreneur stopped work for a year after experiencing demoralization.

With his family's financial support, the entrepreneur continued his seaweed research work and after realizing that seaweed farming business was not viable, he changed the course of his business and instead of selling dried seaweed as a raw material, he sought new seaweed uses in new niche markets.

First the entrepreneur was intensily searching for seaweed traders for fertilizers and human consumption, after that the entrepreneur started working in Crosland Técnica, the first seaweed exporter in Peru. The entrepreneur helped them relaunch their seaweed division and contacted new international traders for the enterprise. These traders had specific seaweed requirements such as the seaweed coloring process being as natural as possible and the entrepreneur managed to achieve this because of his undergraduate thesis experience.

In 2002, the entrepreneur and his partner established an enterprise to outsource seaweed cultivation and production from Crosland Technique.

\section{Startup and First Years}

The entrepreneur began in the best possible way with seaweed export to Chile. However, after many years the enterprise had low profitability; thus, his family helped him develop the enterprise's Research and Development (R\&D) area. By 2006 they already had a portfolio of 10 products and $50 \%$ international sales. Despite that, in the same year they decided to stop exporting seaweed due to the emergence of new sellers. Subsequently, they restructured their business strategies to stay ahead of the competition but failed to achieve the desired results and the entrepreneur started a new undertaking to strengthen his international brand.

The enterprise was established in 2007 and since its inception has had an R\&D area with highly trained professional staff. Through the development of innovative seaweed-based products, the enterprise diversified mainly into agriculture, nutrition, and cosmetics. During the enterprise's growth stage, the entrepreneur created innovation projects in genetics and seaweed farming and he presented them to the Science and Technology Program (FINCYT) and INNOVATE PERU, through an alliance with the Agrarian University.

In 2016, the enterprise underwent a recapitalization process; however, the entrepreneur's shares failed to stabilize and majority of the shareholder's prevailed. Therefore, the entrepreneur had to leave the enterprise's general management. The changes implemented by the new management did not follow the founder's culture and philosophy, thus he resigned from the enterprise in 2017.

\section{Intellectual Property}

Patents were not beneficial for the entrepreneur. He had a bad experience with INDECOPI. The company decided not to patent its products and processes, which were protected only by the trade secret. It was even more difficult abroad. The enterprise partly developed its product, cutting off communication between different plants to avoid leaks.

The most important patent applications filed by the entrepreneur included a patent for natural seaweed coloring process and another one for seaweed fertilizers. The coloring patent application was filed in 2004 with INDECOPI and was rejected in 2009. The entrepreneur argued that the examiner was not competent since he mistook his invention for a seaweed amino acid issue, and asked for another examiner. However, the court ended up favoring the examiner. Similarly, he filed an application for a seaweed fertilizer patent at the end of 2007. This was rejected because an opponent surfaced immediately after the application was made. 


\section{Case 2}

\section{Enterprise Profile}

The enterprise focuses on sustainable and environmental production of Sphagnum Moss for export and economic impact on the country's high Andean areas. It was founded in 2010 with the aim of improving the quality of life of those living within its economic influence area through inclusion and sustainability, social integration, and economic development. The enterprise began exporting in 2010. It currently exports to China, Japan, and the United States.

\section{Founder's Academic Background and Experience}

The entrepreneur is a former student of the University of Lima, Management Faculty. Later, he specialized in logistics at ESAN University and worked at La Fabril, now known as Alicorp, as a trainee in the marketing and logistics areas of the dental division. He then worked another internship in Formetal, an enterprise managed by a professor at the Management Faculty of the University of Lima. This professor provided him with significant training in his work area. He considers these internships important, since he acquired skills that would help him in his future entrepreneurship.

Eventually he worked at Cerámica Lima, now known as Celima, an enterprise that helped him gain considerable work experience as he climbed the corporate ladder to become an assistant logistics manager. However, after some drastic changes in the enterprise, the entrepreneur decided to establish his first enterprise in 2000.

The enterprise was his first venture and he researched the gas market for 6 months by using his prior knowledge and contacts he made had in Italy while working in Celima. The entrepreneur even sold a line of business, namely converted gas filling stations, to finance the enterprise's restructuring and research prior to founding the moss venture.

\section{Background and In-Depth Training}

In 2007 and 2008, he performed some product tests designed for the moss enterprise in New Zealand; however, it proved difficult to export natural products. In the intermediate phase, the entrepreneur contacted Sierra Exportadora (a national export promotion program funded by the Peruvian state), who were also interested in developing moss-based products. They introduced him to a worldwide pioneer in the moss industry, who later become his mentor on moss issues.

The pioneer (a worldwide moss researcher), on his first trip to Cusco in Peru had found moss similar to that of New Zealand and Chile (the world's only exporters at that time). Then the pioneer and the entrepreneur made a trip in 2009, thanks to Sierra Exportadora, to Junin, Peru to discover more moss harvesting areas and gain know-how, while simultaneously noticing the harsh reality of the high Andean communities.

As a result of his good credit score from his first venture (gas), his enterprise project was supported by bank investments. However, the entrepreneur considered that he needed a formal business plan, thus he entered a contest called "TechnoServe" (a NGO for startups). He spent a year writing a complete business plan: from product description, SWOT analysis (strengths, weaknesses, opportunities and threats) to production and investment, among other aspects. Even though the entrepreneur only reached the semifinal, he claims, "what mattered to me was the business plan." During that year, he managed to obtain additional financing from InCapital, the angel investment network and BiD Network contest.

The enterprise was established in 2010 with the goal of capitalising from Sphagnum Moss, a resource appreciated globally and which grows abundantly in the humid high areas of the Peruvian Andes. The impact it creates is a distinctive factor, since the supply and production process directly and sustainably involves inhabitants of communities that live in extreme poverty. It also involves the recovery of wastelands (as before, moss was burned due to a lack of awareness) and the revaluation of communal lands. 
During subsequent years, the entrepreneur interacted with specialists in water filter projects from the Universidad Cayetano and Universidad del Centro. He began to assign importance to the R\&D of new products not implemented in the beginning.

\section{Market Orientation}

Moss is used as a horticultural substrate, specifically and traditionally for orchids, since orchids are generally not planted in soil like other houseplants but in a special substrate such as moss, the natural habitat for orchid growing. Asian people have an orchid growing culture and therefore buy moss for orchid care, says the entrepreneur.

Therefore, they first targeted Asian countries, such as Japan, Korea, and Thailand. They began with a good start says the entrepreneur, "at a good level," but they faced a lack of continuity, i.e., a container was ordered in April and then more were ordered in September and October, without them finding out whether the product had worked or if there was anything wrong. Later, the entrepreneur learned that customers claimed they had to wait for the whole plant growth process to notice a reaction. However, they had to continue covering the enterprise's fixed costs because they did not know what else to do. It was a very difficult stage as they had hired very valuable people and could not support them.

\section{Future Plans}

The enterprise began to sell its products in traditional (larger) dispenses of 5-kilos, and since 2015 they have been developing 4 sales dispenses for other market segments such as homemakers, who buy smaller packages online with value added and thereby at a higher price. According to the entrepreneur, homemakers buy moss for their pots: "in Peru we do not have that culture, but, for example, in Asia, specifically in Japan, buying substrate is very common because they grow their plants as part of their culture, so it's a pretty large market." The entrepreneur is looking to participate in more events and contests that can finance his innovation and development projects for moss-based products.

\section{Case Analysis}

Entrepreneurs have a common profile, that is, they have higher education degrees, are experts in their field, cannot speak English fluently, have a global vision, and have entrepreneurial capabilities.

Both cases use a similar network typology comprising families, undergraduate and graduate professors, public and private organizations, and events according to what Hallen (1992) proposed. However, the network infrastructure has certain differences such as the University, because the perceived as an institution net is different from the professor net. Thus, the differentiation between personal and professional networks is not sufficient; a broader typology should be explored, since networks generate various benefits related to the accelerated internationalization process.

Networks generate multiple benefits such as helping establish contacts, non-financial resources (laboratories, office, equipment, among others), financial resources (credit access, guarantees, recommendations), access to previous experiences (reference letters, work experience stories, among others), counseling, emotional support, different types of contacts (customers, suppliers, workers, among others), different types of knowledge (specific, general, and key), different types of information (reports, plans, data, among others), and inter alia, which are supported by the credibility and trust facilitated by networks according to Bucklin and Sengupta (1993); Larson (1992). Entrepreneurs should not simply assess these multiple benefits and their intensity, they should explore their existence as well as their specific contribution to the acceleration process (MAJKGARD and SHARMA, 1998; SHARMA and BLOMSTERMO, 2003).

These benefits contributed to each construct of the proposed Born Global/International New Venture model. The network of partners and previous work and contacts generated by events contributed to international market orientation, complementing Burt's (1997) proposal. In contrast, undergraduate and graduate professors' previous work and scientific events helped secure knowledge for R\&D-based specialization and the development of knowledge-intensive products through networks, as proposed by Ritter and Gemünden (2003) and Chetty (2004). 
Partners as well as public and private institutions promote access to resources, while the network of undergraduate professors and previous work facilitates access to previous experiences. In both cases, the family provided emotional support in times of the enterprises' crisis.

Enterprises have proved to be vulnerable since they start with a single product, as proposed by Mort and Weerawardena (2006), while network creation and evolution thereof have been guided by the internationalization strategy (market-oriented and/or R\&D-based specialization).

We could group the network typology according to the benefit achieved, while one case focused on building a network that contributed to knowledge, the other aimed at a network that contributed to market extension. Case 1 takes advantage of a group of networks to gain knowledge, while case 2 intends to open up new markets.

\section{Box 2}

Network Benefit Matrix in the Accelerated Internationalization Model for Seaweed (2018)

\begin{tabular}{|c|c|c|c|c|c|c|c|c|}
\hline \multicolumn{9}{|c|}{ NETWORK TYPOLOGY } \\
\hline $\begin{array}{c}\text { Born Global } \\
\text { Characteristcs }\end{array}$ & Family & $\begin{array}{c}\text { Undergraduate } \\
\text { Professors }\end{array}$ & $\begin{array}{l}\text { Graduate } \\
\text { Professors }\end{array}$ & Partners & $\begin{array}{l}\text { Previous } \\
\text { Work }\end{array}$ & $\begin{array}{l}\text { University } \\
\text { (Institute) }\end{array}$ & $\begin{array}{c}\text { Public and } \\
\text { Private } \\
\text { Organizations }\end{array}$ & Events \\
\hline $\begin{array}{l}\text { International } \\
\text { Market } \\
\text { Orientation }\end{array}$ & & & & $\begin{array}{l}\text { Facilitated } \\
\text { contacts }\end{array}$ & $\begin{array}{c}\text { Facilitated } \\
\text { contacts }\end{array}$ & & & $\begin{array}{c}\text { Facilitated } \\
\text { contacts }\end{array}$ \\
\hline $\begin{array}{l}\text { Specialization } \\
\text { (Product R\&D) }\end{array}$ & & $\begin{array}{l}\text { Provided } \\
\text { knowledge }\end{array}$ & $\begin{array}{l}\text { Provided } \\
\text { specialized } \\
\text { knowledge }\end{array}$ & & $\begin{array}{l}\text { Provided } \\
\text { knowledge }\end{array}$ & & & $\begin{array}{c}\text { Facilitated } \\
\text { contacts }\end{array}$ \\
\hline $\begin{array}{l}\text { Access to } \\
\text { Resources }\end{array}$ & $\begin{array}{l}\text { Provided } \\
\text { resources }\end{array}$ & & & $\begin{array}{c}\text { Provided } \\
\text { financing for } \\
\text { laboratories }\end{array}$ & & $\begin{array}{c}\text { Provided } \\
\text { laboratories }\end{array}$ & $\begin{array}{l}\text { Provided } \\
\text { financing }\end{array}$ & \\
\hline $\begin{array}{c}\text { Team } \\
\text { Formation }\end{array}$ & $\begin{array}{c}\text { Facilitated } \\
\text { contacts }\end{array}$ & & & $\begin{array}{c}\text { Complemented } \\
\text { the team }\end{array}$ & $\begin{array}{l}\text { Work with } \\
\text { ex-partners }\end{array}$ & $\begin{array}{c}\text { Facilitated } \\
\text { staff } \\
\text { recruitment }\end{array}$ & & \\
\hline $\begin{array}{c}\text { Previous Work } \\
\text { Experience }\end{array}$ & $\begin{array}{c}\text { Facilitated } \\
\text { contacts }\end{array}$ & $\begin{array}{c}\text { Diving } \\
\text { activities and } \\
\text { projects }\end{array}$ & $\begin{array}{c}\text { Laboratory } \\
\text { works }\end{array}$ & & $\begin{array}{c}\text { Performed } \\
\text { work }\end{array}$ & & & \\
\hline $\begin{array}{l}\text { Frustration } \\
\text { Tolerance }\end{array}$ & $\begin{array}{c}\text { Provided } \\
\text { emotional } \\
\text { support }\end{array}$ & & & & & & & \\
\hline $\begin{array}{c}\text { Professional } \\
\text { Profile }\end{array}$ & $\begin{array}{l}\text { Provided } \\
\text { resources } \\
\text { and advice }\end{array}$ & $\begin{array}{l}\text { Oriented as } \\
\text { academic } \\
\text { models and } \\
\text { provided } \\
\text { contacts }\end{array}$ & $\begin{array}{c}\text { Provided } \\
\text { knowledge } \\
\text { and contacts }\end{array}$ & & & & & \\
\hline
\end{tabular}

Source: Elaborated by the author (2018). 
Box 3

Network Benefit Matrix in the Accelerated Internationalization Model for Moss (2018)

\begin{tabular}{|c|c|c|c|c|c|c|}
\hline \multicolumn{7}{|c|}{ NETWORK TYPOLOGY } \\
\hline $\begin{array}{l}\text { Benefits to the } \\
\text { Born Global Model }\end{array}$ & Family & $\begin{array}{c}\text { Undergraduate } \\
\text { Professors }\end{array}$ & Partners & $\begin{array}{l}\text { Previous } \\
\text { Work }\end{array}$ & $\begin{array}{c}\text { Public and Private } \\
\text { Organizations }\end{array}$ & Events \\
\hline $\begin{array}{c}\text { International } \\
\text { Market Orientation }\end{array}$ & & & $\begin{array}{l}\text { Facilitated } \\
\text { contacts }\end{array}$ & $\begin{array}{c}\text { Facilitated } \\
\text { contacts }\end{array}$ & $\begin{array}{c}\text { Facilitated } \\
\text { contacts }\end{array}$ & $\begin{array}{c}\text { Facilitated } \\
\text { contacts }\end{array}$ \\
\hline $\begin{array}{l}\text { Specialization } \\
\text { (Product R\&D) }\end{array}$ & & & \begin{tabular}{|c|} 
Provided product \\
specialization
\end{tabular} & & $\begin{array}{l}\text { Provided as } \\
\text { business plan }\end{array}$ & $\begin{array}{l}\text { Provided } \\
\text { knowledge }\end{array}$ \\
\hline $\begin{array}{l}\text { Access to } \\
\text { Resources }\end{array}$ & & & $\begin{array}{l}\text { Provided financing } \\
\text { and knowledge }\end{array}$ & & $\begin{array}{l}\text { Provided } \\
\text { financing }\end{array}$ & $\begin{array}{l}\text { Provided } \\
\text { knowledge }\end{array}$ \\
\hline $\begin{array}{c}\text { Team } \\
\text { Formation }\end{array}$ & & & $\begin{array}{l}\text { Facilitated } \\
\text { contacts }\end{array}$ & & $\begin{array}{l}\text { Facilitated } \\
\text { contacts }\end{array}$ & \\
\hline $\begin{array}{l}\text { Previous Work } \\
\text { Experience }\end{array}$ & & $\begin{array}{c}\text { Provided knowledge } \\
\text { and work }\end{array}$ & $\begin{array}{l}\text { Provided } \\
\text { experience }\end{array}$ & $\begin{array}{l}\text { Performed } \\
\text { work }\end{array}$ & $\begin{array}{l}\text { Provided } \\
\text { experience }\end{array}$ & \\
\hline $\begin{array}{c}\text { Frustration } \\
\text { Tolerance }\end{array}$ & $\begin{array}{c}\text { Provided } \\
\text { emotional support }\end{array}$ & $\begin{array}{c}\text { Provided emotional } \\
\text { support }\end{array}$ & & & & \\
\hline Professional Profile & & & & $\begin{array}{l}\text { Provided } \\
\text { knowledge }\end{array}$ & & \\
\hline
\end{tabular}

Source: Elaborated by the author (2018).

The benefits identified stem from different types of networks, although the internationalization strategy (product or market) seems oriented toward specialized networks. An enterprise such as the seaweed's, is oriented toward innovation and specialization and should build networks that allow it to be on the leading edge of knowledge. Whereas, the mature moss enterprise intended to create a local academic network that helped it develop its product. This complements Ferreira, Santos, and Serra's (2010) proposal, showing how the network typology generates specific benefits that contribute to a highly competitive product.

\section{Box 4}

\section{Benefit and Network Type Matrix for Seaweed (2018)}

\begin{tabular}{|c|c|c|c|c|c|c|c|c|c|}
\hline SEAWEED & & & & NETV & ORK TYP & OGY & & & \\
\hline $\begin{array}{c}\text { Benefits to the } \\
\text { Born Global } \\
\text { Model }\end{array}$ & Family & $\begin{array}{c}\text { Undergraduate } \\
\text { Professors }\end{array}$ & $\begin{array}{l}\text { Graduate } \\
\text { Professors }\end{array}$ & Scientists & Partners & $\begin{array}{c}\text { Previous } \\
\text { Work }\end{array}$ & $\begin{array}{l}\text { University } \\
\text { (Institute) }\end{array}$ & $\begin{array}{c}\text { Public and } \\
\text { Private } \\
\text { Organizations }\end{array}$ & Events \\
\hline $\begin{array}{l}\text { Provided and/ } \\
\text { or Facilitated } \\
\text { Contacts }\end{array}$ & $x$ & $x$ & $x$ & & $x$ & $x$ & & & $x$ \\
\hline $\begin{array}{c}\text { Previded General } \\
\text { or Specialized } \\
\text { Knowledge }\end{array}$ & & $x$ & $x$ & $x$ & & & $x$ & & \\
\hline $\begin{array}{l}\text { Provided and/ } \\
\text { or Financed } \\
\text { Resources }\end{array}$ & $x$ & & & & $x$ & & $x$ & $x$ & \\
\hline $\begin{array}{c}\text { Provided Work } \\
\text { Experience }\end{array}$ & & $x$ & & & $x$ & $x$ & & & \\
\hline $\begin{array}{l}\text { Provided } \\
\text { Emotional } \\
\text { Support }\end{array}$ & $x$ & & & & & & & & \\
\hline
\end{tabular}

Source: Elaborated by the author (2018). 
Box 5

Benefit and Network Type Matrix for Moss (2018)

\begin{tabular}{|c|c|c|c|c|c|c|}
\hline \multicolumn{2}{|c|}{ MOSS } & NETWORK TYPOLOGY \\
\hline $\begin{array}{c}\text { Benefits to the Born } \\
\text { Global Model }\end{array}$ & Family & $\begin{array}{c}\text { Undergraduate } \\
\text { Professors }\end{array}$ & Partners & $\begin{array}{c}\text { Previous } \\
\text { Work }\end{array}$ & $\begin{array}{c}\text { Public and Private } \\
\text { Organizations }\end{array}$ & Events \\
\hline $\begin{array}{c}\text { Provided and/or } \\
\text { Facilitated Contacts }\end{array}$ & & $X$ & $X$ & $X$ & $X$ & $X$ \\
\hline $\begin{array}{c}\text { Previded General or } \\
\text { Specialized Knowledge }\end{array}$ & & $X$ & $X$ & $X$ & $X$ \\
\hline $\begin{array}{c}\text { Provided and/or } \\
\text { Financed Resources }\end{array}$ & & $X$ & $X$ & $X$ & $X$ & \\
\hline $\begin{array}{c}\text { Provided Work } \\
\text { Experience }\end{array}$ & $X$ & & & & \\
\hline $\begin{array}{c}\text { Provided Emotional } \\
\text { Support }\end{array}$ & $X$ & & & & $X$ \\
\hline
\end{tabular}

Source: Elaborated by the author (2018).

The types of networks according to their origin (family, undergraduate and graduate professors, partners, previous work, universities, public and private organizations, and contacts generated by events) do not show an exclusive behavior with respect to the benefits related to trusted contacts and general knowledge, i.e., any type of network can entail these benefits. The relationship between network types, based on their origin and benefits, does not rely on a clear and common structure, which, in addition, is impossible to deduce based on two cases with different internationalization strategies. Therefore, the relationship between the network infrastructure and its benefits in the accelerated internationalization process is complex and displays a vague network of dynamics, in accordance with Coviello's (2006) proposal.

\section{Figure 3}

\section{Networks according to Entrepreneurial Process Stages}

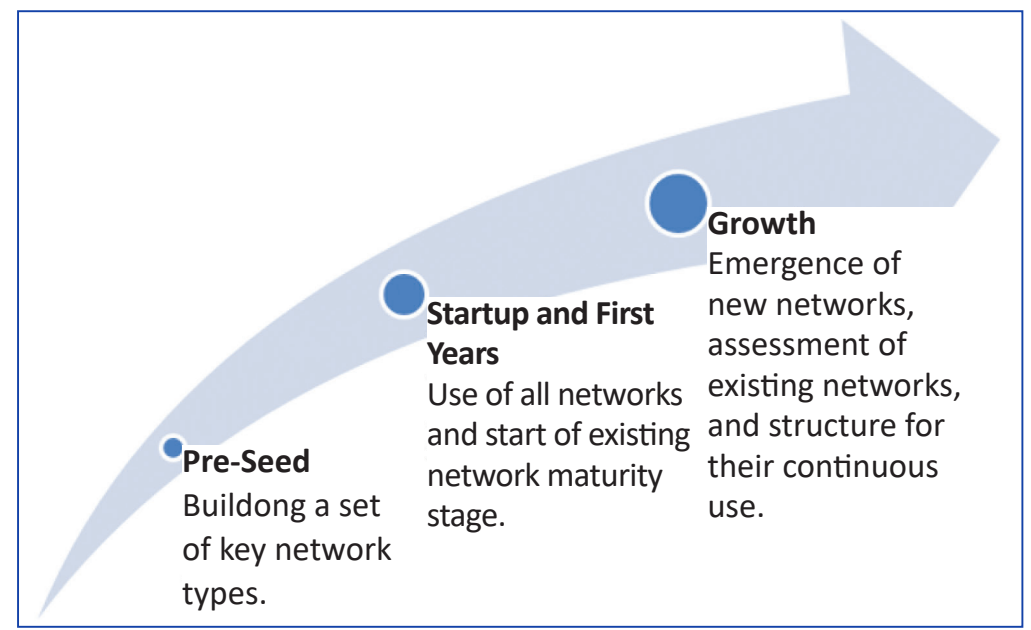

Source: Elaborated by the author (2018).

In terms of network dynamics over time, the pre-seed stage is characterized by the emergence of several networks, which are then used on a combined basis in the startup stage. This corresponds to Coviello's (2006) conclusions that report an evolution throughout the business life cycle, contradicting Sharma and Blomsterno (2003) who propose that INVs do not have a network behavior pattern. 
The pre-seed stage shows previously built networks that can be used in the startup and first years, and influence the internationalization strategy that is crucial to enterprise emergence. Later, these networks mature along with the enterprise, thereby entailing the need for new networks, albeit conditioned by a defined strategy, which assesses the benefit of existing networks and the emergence of new ones. This partially explained what Jones and Coviello (2005) argued, "the network influences internationalization and internationalization influences the network, over time."

In the enterprise maturity stage, entrepreneurs become more skilled in network management and more aware of their value and significance for the internationalization process and business profitability.

\section{FINAL CONSIDERATIONS}

This research classifies the typology of networks by origin and details the benefits they generate to accelerate key factors of a rapid internationalization process.

For a more comprehensive understanding of network dynamics, we first explore a more detailed network typology, which clearly shows the contribution of family, undergraduate and graduate professors, university, partners, previous work, public and private organizations, and contacts generated by events. It also highlights network benefits such as the ease of establishing contacts, non-financial resources (laboratories, office, equipment, among others), financial resources (credit access, guarantees, recommendations), access to previous experiences (reference letters, work experience stories, among others), counseling, emotional support, various types of contacts (customers, suppliers, workers, among others), different types of knowledge (specific, general, and key), different types of information (reports, plans, data, among others), and inter alia. Through this classification we approach construct operationalization in order to launch future quantitative studies about the impact of these benefits on factors accelerating small- and medium-sized enterprise internationalization.

The research examines the association between network types by origin and the benefits, finding a possible pattern where partners as well as public and private organizations facilitate the access to resources, undergraduate professors and previous works generate previous experiences, and the family provides emotional support. Further research could delve into this behavior in rapid internationalization enterprises and indicate that benefits such as a trusted contact network and general knowledge are not strongly linked with any type of network according to its origin.

The study shows the relationship between the type of network and strategy, namely a relationship between international market orientation with the contribution of partners, previous work, and contacts generated through events. Furthermore, a R\&D-based specialization is enhanced by a network of undergraduate and graduate professors, previous work, and scientific or specialized events with the aim of gaining knowledge.

The entrepreneurs spontaneously reported the types of networks and valuation thereof during interviews; however, the lack of suppliers and customers is especially noteworthy. This may be because both enterprises are small and do not have a dominant position. They do not fit into a global supply chain that directly provides information, knowledge, and financing, since the customers are large distributors and their suppliers are low-income families or microentrepreneurs. We identified networks that develop two areas of knowledge: academic and commercial, which do not easily interconnect. Therefore, these networks have specific roles and barriers that each entrepreneur manages to overcome according to their capabilities.

The entrepreneurs exploited the networks built in the pre-seed stage to gain knowledge, contacts, and resources that accelerated their internationalization process. The networks created in the pre-seed stage were crucial to guiding the venture internationalization strategy. The entrepreneur who began with academic knowledge networks developed a product innovation strategy, while the entrepreneur with commercial knowledge networks was oriented toward the marketplace. 
The key networks created in the pre-seed stage mature in the startup stage, reinforcing the internationalization strategy. Later in the growth stage, the enterprises expanded their strategy, combining innovation with market growth and assigning them the same importance. This evolution pattern in network management and internationalization strategy could be investigated in subsequent research on the accelerated internationalization of small- and medium-sized agriculture exporting companies.

The preliminary exploratory analysis and selected cases show that a product with little or no local demand and with an international niche market promotes rapid internationalization ventures. Exploratory experience can guide new research on emerging agriculture export markets, since rapid internationalization ventures are hard to find in emerging markets.

Future research should analyze and understand the capabilities and/or actions for the proper management of business networks that accelerate the internationalization process. This may imply a method not easily noticed, such as a search for contacts with established profiles and network monitoring instruments. 


\section{REFERENCES}

ANDERSSON, I.; WICTOR, I. Innovative internationalization strategies in new firms: born globals Swedish case. Journal of International Entrepreneurship, v. 1, n. 3, p. 249-276, 2003.

ARENIUS, P. Creation of firm-level social capital, its exploitation, and the process of early internationalization. Journal of International Entrepreneurship, v. 1, p. 415-417, 2002.

ASPELUND, A.; MOEN, O. A generation perspective on small firm internationalisation: from a traditional exporters and flexible to born globals. Reassessing the Internationalization of the Firm, v. 11, p. 195-223, 2001.

AUTIO, E.; SAPIENZA, H. Comparing process and Born Global Perspectives in the International Growth of Technology - based new firms. Frontiers of Entrepreneurship Research, p. 413-424, 2000.

BAKER, S. E.; EDWARDS, R. How many qualitive interviews is enough? Expert voices and early carrer reflections on sampling and cases in qualitive research. Southampton: National Centre of Research Methods, 2012.

BELL, J. The internationalization of small computer software firms: a further challenge to stage theories. European Journal of Marketing, v. 29, n. 8 , p. $60-75,1995$.

BUCKLIN, L. P.; SENGUPTA, S. Organizing successful co-marketing alliances. Journal of Marketing, v. 57, n. 2, p. 32-46, 1993.

BURGEL, O.; MURRAY, G. The international market entry choices of start-up companies in high-technology industries. Journal of International Marketing, v. 8, n. 2, p. 33-62, 2000.

BURT, R. A note on social capital and network content. Social Networks, v. 19, n. 4, p. 355-373, 1997.

CANNONE, G. et al. Drivers of International development for born global companies founded by italian entrepreneurs. In: INTERNATIONAL SYMPOSIUM ON ENTREPRENEURSHIP AND INNOVATION, 24., 2012, Venice. Proceedings... Venice: Università degli Studi dell'Insubria, 2012. p. 1-32.

CHETTY, S.; BLANKENBURG-HOLM, D. Internationalisation of small to medium-sized manufacturing firms: a network approach. International Business Review, v. 9, n. 1, p. 77-93, 2000.

CHETTY, S.; CAMPBELL-HUNT, C. A strategic approach to internationalization: a traditional versus a "Born-Global" approach. Journal of International Marketing, v. 12, n. 1, p. 57-81, 2004.

COVIELLO, N. E. The network dynamics of international new ventures. Journal of International Business Studies, v. 37, n. 5, p. 713-731, 2006.

COVIELLO, N.; MUNRO, H. Growing the entrepreneurial firm: networking for international market development. European Journal of Marketing, v. 29, n. 70, p. 49-61, 1995.

COVIELLO, N.; MUNRO, H. Network relationships and the internationalisation process of small software firms. International Business Review, v. 6, n. 4, p. 361-386, 1997.

EISENHARDT, K. Building theories from case study research. Academy of Management Review, v. 14, n. 4, p. 532-550, 1989.
ELLIS, P. Social ties and foreign market entry. Journal of International Business Studies, v. 31, n. 3, p. 443-470, 2000.

EVERS, N.; KNIGHT, J. Role of international trade shows in small firm internationalization: a network perspective. International Marketing Review, v. 25, n. 5, p. 544-562, 2008.

FALIZE, M.; COEURDEROY, R. The network approach to rapid internationalization among born global and born again global firms: the case of the "global innovation network. Ottignies-Louvain-laNeuve: Louvain School of Management Research Institute, 2012. (Working Paper Series, nov. 2012). p. 1-29.

FEDERICO, J. et al. Does entrepreneur's human and relational capital affect early internationalisation? A cross-regional comparison. European J. of International Management, v. 3, n. 2, p. 199-2015, 2009.

FERREIRA, M.; SANTOS, J.; SERRA, F. The international entrepreneurial firms' social networks. Cadernos EBAPE.BR, Rio de Janeiro, v. 8, n. 1, p. 133-145, 2010.

GABRIELSSON, M.; KIRPALANI, V. Born globals: how to reach new business space rapidly. International Business Review, v. 13, n. 5, p. 555-571, 2004.

GALASKIEWICZ, J.; ZAHEER, A. Networks of competitive advantage. Research in the Sociology of Organizations, v. 16, p. 237-261, 1999.

GESTIÓN. Agroexportaciones superarán los US\$ 6,000 millones el 2016. Diario Gestión, Lima, 01 jan. 2016.

GULATI, R. Does familiarity breed trust? the implications of repeated ties for contractual choice in alliances. The Academy of Management Journal, v. 38, n. 1, p. 85-112, 1995.

HALLEN, L. Infrastructural networks in international business. In: FORSGREN, M. (Ed). Managing networks in international business. New York: Routledge, 1992. p. 77-92.

HAYES, S. et al. Experiential avoidance and behavioral disorders: a functional dimensional approach to diagnosis and treatment. Journal of Consulting and Clinical Psychology, v. 64, n. 6, p. 1152-1168, 1996.

HINTTU, S.; FORSMAN, M.; KOCK, S. Mission impossible internationalization without social networks. London: Edward Elgar, 2003.

HOLMLUND, M.; KOCK, S. Relationships and the internationalization of finnish small and medium-sized companies. International Small Business Journal, v. 16, n. 4, p. 46-63, 1998.

HUNT, S. Modern marketing theory: critical issues in the philosophy of marketing. Cincinnati: Southwestern, 1991.

JOHANSON, J.; MATTSSON, L. G. Internationalization in industrial systems - a network approach. Strategies in Global Competition, p. 303-321, 1998.

JOHANSON, J.; VAHLNE, J. Management of foreign market entry. Scandinavian International Business Review, v. 1, n. 3, p. 9-27, 1992.

JOHANSON, J.; VALHNE, J. E. The Uppsala internationalization process model revisited: From liability of foreings to liability of outsidership. Journal International Business, v. 40, n. 9, p. 1411-1431, 2009. 
JONES, M. The internationalization of small high-technology firms. Journal of International Marketing, v. 7, n. 4, p. 15-41, 1999.

JONES, M.; COVIELLO, N. Internationalisation: conceptualising an entrepreneurial process of behaviour in time. Journal of International Business Studies, v. 36, n. 3, p. 284-303, 2005.

KANTIS, H.; FEDERICO, J.; IBARRA GARCÍA, S. Condiciones sistémicas para el emprendedorimos dinámico 2016: novedades y tendencias para fortalecer e integrar los ecosistemas de la región. Buenos Aires: Asociación Civil Red Pymes Mercosur, 2016.

KNIGHT, G.; CAVUSGIL, S. The born global firm: a challenge to traditional internationalization theory. Advances in International Marketing, v. 8, p. 11-26, 1996.

KNIGHT, G.; CAVUSGIL, S. T. Innovation, organizational capabilities, and the born global. Journal of International Business Studies, v. 35, n. 2, p. 124-141, 2004.

LARSON, R. Evaluation of advanced retrieval techniques in an experimental online catalog. Journal of the American Society for Information Science, v. 43, n. 3, p. 34-53, 1992.

LIEBESKIND, J. Knowledge, strategy, and the theory of the firm. Strategic Management Journal, v. 17, n. esp., p. 93-107, 1996.

MADSEN, T.; SERVAIS, P. The internationalization of Born Globals: an evolutionary process? International Business Review, v. 6, n. 6, p. 561-583, 1997.

MAJKGARD, A.; SHARMA, D. Client-following and market-seeking strategies in the internationalization of service firms. Journal of Business-to-Business Marketing, v. 4, n. 3, p. 1-41, 1998.

MCDOUGALL, P. P; OVIATT, B. M. Some Fundamental Issues in International Entrepreneurship. Entrepreneurship Theory \& Practice, p. 1-27, jul. 2003.

MELIN, L. Internationalizarion as a strategy process. Strategic Management Journal, 1992. p. 99-118.

MÉNDEZ, C. Análisis del comportamiento de internacionalización de pequeñas y medianas empresas exportadoras. El caso de empresas exitosas de la industria del software en Lima. Sotavento MBA, n. 25, p. 18-24, 2015.

MORT, G.; WEERAWARDENA, J. Networking capability and international entrepreneurship: How networks function in Australian born global firms. International Marketing Review, v. 23, n. 5, p. 549-572, 2006.

OVIATT, B.; MCDOUGALL, P. Toward a theory of International New Ventures. Journal of International Business, v. 25, n. 1, p. 45-64, 1994.

OVIATT, B.; MCDOUGALL, P. New venture internationalization, strategic change, and performance: a follow-up study. Journal of Business Venturing, v. 11, n. 1, p. 23-40, 1996.

RENNIE, M. Global competitiveness: born global. The McKinsey Quarterky, n. 4, p. 45-52, 1993.

RIALP-CRIADO, A. et al. The Born Global phenomenon: a comparative case study research. Journal of International Entrepreneurship, v. 3, n. 2, p. 133-171, 2005.

RITTER, T.; GEMÜNDEN, H. Network competence: its impact on innovation success and its antecedents. Journal of business research, v. 56, n. 9, p. 745-755, 2003.

ROBERTS, E.; SENTURIA, T. Globalizing the emerging high-technology company. Industrial Marketing Management, v. 25, n. 6, p. 491506, 1996.

SHARMA, D. D; BLOMSTERMO, A. The internationalization process of Born Globals: a network view. International Business Review, v. 12, n. 6, p. 739-753, 2003.

SHARMA, D.; BLOMSTERMO, A. The internationalization process of Born Globals. Stockholm: The Stockholm School of Economics \& Copenhagen Business School \& Uppsala University, 2002.

STRAUSS, A; CORBIN, J. Basics of qualitative research: grounded theory procedures and techniques. 1. ed. Michigan: University of Michigan, 1990.

VASQUEZ, K. Determinantes del crecimiento Agroexportador. MONEDA: Revista del Banco Central de Reserva del Perú, n. 161, p. 22-28, 2015.

YIN, R. Case study research: design and methods. California: Sage, 1994.

ZAHRA, S.; IRELAND, D.; HITT, A. International expansion by new venture firms; international diversity, mode of market entry, technological lerning, and performance. Academy of Management Journal, v. 43, n. 5, p. 925-950, 2000. 